\author{
Urszula Swoboda-Rydz*
}

\title{
MOVE BEYOND THE TEXT
}

Keywords: reading, comprehension, critical, knowledge, experience

Summary. Reading is a complex skill which is indispensable in order to be successful in pursuing a scientific career. While reading specialist texts, it is necessary to go through the literal, inferential and creative-evaluative levels of comprehension. For an inexperienced reader, who is already familiar with the basic terminology in a relevant field, specialist texts may pose difficulty since they need critical approach. It means using experience and knowledge beyond the text, and also the ability to ask adequate questions. Moving beyond the text gives the reader an opportunity to have an insight into the problem. Two examples used in the workshop show how teachers may prepare students to read specialist texts.

People read scientific and specialist tests in order to know and understand more in a given field. Nowadays, the reader needs to read accurately and critically in many professions. The reader must evaluate the author's words and test the truth against their experience and knowledge (Norozi 2007, p. 1).Reading specialist texts, and other cognitively demanding ones, involves concentration and mental discipline to analyse different dimensions of the text in order to reach a deeper understanding. Fisher and Frey (2012) and Richards (1929) added the need of "emphasizing the particular over the general" (as cited in Lapp et al., 2013, p. 111).Therefore, the reader must have cognitive capacities, purpose for reading and linguistic and non-linguistic knowledge (Snow 2002, p. 12).

\section{READING COMPREHENSION}

Comprehension involves three interrelating elements: the reader, the text, and the activity or purpose for reading. The term reading comprehension is defined as "the process of simultaneously extracting and constructing meaning through in-

*urydz22@gmail.com, Centrum Języka Polskiego i Kultury Polskiej dla Cudzoziemców „Polonicum”, Uniwersytet Warszawski, 00-927 Warszawa, ul. Krakowskie Przedmieście 26/28; Studium Języków Obcych, Warszawski Uniwersytet Medyczny, 02-109 Warszawa, ul. Księcia Trojdena 2a. 
teraction and involvement with written language". (Snow 2002, p. XIII-XIV). In the process of reading, the reader must pass the following levels (Barrett's Taxonomy of Reading Comprehension):

- level of inference - in order to predict the outcome and associate meanings,

- level of evaluation - in order to make judgements based on solid criteria,

- level of appreciation - in order to respond to the text and the language and to generate imagination (Griffin 2005, p.17).

The above levels can be implemented in the classroom and teachers may help use appropriate strategies to reach them.

Pearson and Johnson (1978) distinguished three aspects in the process of reading:

- $\quad$ reading in the lines

- $\quad$ reading between the lines

- reading beyond the lines.

They suggested using specific questions to the text by teachers during the text analysis. First, questions associated with the answers which are directly stated in the text. The question could be: "When was he born?" or "Why did he leave the job?" The only condition to answer them is to read carefully "the lines" and find the details. Reading between the lines allows to understand implications of the text. The reader has to spot the implications, overtones, premonitions, insinuations and other clues which have been mentioned "between the lines". The possible questions may be: "What can be inferred from the hero's behaviour?" The third type of questions depends on the reader's background knowledge. There are no clues in the text, but the author assumes that the reader has already been introduced to the subject matter(thanks to books, articles, or lectures). Reading beyond the lines lets the reader answer questions dependent on the experience and the reader's knowledge (Griffin 2005, p. 17). Both questions and answers reach beyond the text; while the text may be used as a starting point for a discussion. There is some controversy whether the three levels are interdependent and the reader has to move with a full comprehension from a lower lever to another one, but the issue will not be discussed here.

A point should be made that reading beyond the lines often applies to scientific, specialist texts. Looking beyond the text may mean: looking for connections with the reader's (prior) knowledge, selecting additional information relevant to the text, and using different sources of information. The same is true for non-scientific texts. However, while reading a novel the reader keeps closely to the narrative and plot and is not supposed to refer to other novels. In case of fiction, life experience may be needed for the interpretation of the plot. 


\section{READING SPECIALIST TEXTS}

It remains remarkable that, in contrast to general language, specialist language is characterized by monosemy, a simplification of the grammatical system, a word formation based on borrowings from classical languages (Greek, Latin) and a wide lexicon (Gumovskaya 2003, p. 70). Specialist language is precise, concise, and monoreferential (Sawicka 2009, p. 194). The style is neutral or unmarked, there are few figures of speech and emphatic structures (QCAA 2015, p. 5).

Word identification and understanding is important in the initial phase of learning to read. It is usually limited vocabulary which leads to poor reading comprehension (Nation 2004, p. 263; Perfetti 2007, p. 378). Perfetti made a point that "reading comprehension deficits are often associated with word-level decoding difficulties" (Nation 2008, p. 252). Poor linguistic competence may also interrupt reading comprehension. Readers who are less proficient linguistically easily overload their working memory capacity and cannot activate relevant representations in their mind. Less skilled readers possess less attention resources and become easily distracted, so the reading process becomes ineffective (Scott 2005: 37). The literal level must be first mastered but for more proficient readers of a foreign language this level is not sufficient to guarantee comprehension of specialist text.

Apart from lexicon and broadly understood linguistic proficiency, prior knowledge is usually necessary to understand a specialist text. The text (a book, an article) is assessed as difficult when there is no sufficient prior knowledge. Moreover, while reading effectively, a representation of the ongoing text must be created in the mind of the reader. The knowledge must be embedded in a wider context of knowledge available to the reader. It is often assumed that the knowledge of the reader is the same or similar to that of the author (Andrychowicz-Trojanowska, 2010 , p.17). However, readers may differ greatly in terms of knowledge and skills.

Daunis and Iams (2007, pp. 14-19) present five essential reading skills used by proficient readers, which include having expectations about the content, locating oneself in the text, envisioning what comes next, inferring and synthesizing. Here, locating oneself in the text involves activating prior knowledge, making connections with the information that the reader remembers and asking oneself questions beyond the content. The theory works for both fiction and non-fiction texts.

\section{WORKSHOP}

The workshop was held during the conference in Łódź in May, 2016, dedicated to ODMIANY SPECJALISTYCZNE I STYLISTYCZNE W NAUCZANIU JĘZYKÓW OBCYCH I JĘZYKA POLSKIEGO JAKO OBCEGO/DRUGIEGO 
(Specialist and Stylistic Varietes in Teaching Polish As a Foreign/Second Language). The participants involved were mainly teachers of Polish as a foreign language. All of them knew English and could communicate easily and a few taught medical English at the university. The aim was to demonstrate that background knowledge was required to successfully complete the task, according to the schedule of a medical interview and establish the diagnosis.

The author supplied the participants with her own and authentic materials, conducted the workshop and, finally, pointed to selected sources and gave necessary explanations. Each participant had an opportunity to check if they could complete the task themselves or a guidance was needed. The result of reading effectiveness was checked in a discussion.

\section{A MEDICAL INTERVIEW - CASE 1}

First of all, the participants were given a task to conduct a medical interview between a doctor and a patient. The task was carried out in pairs. Details for the patient were provided on a sheet of paper.

\section{The patient:}

You are a 25-year-old marketing manager.

- Your chief complaint is discomfort in the upper part of the abdomen, which started 3-4 months ago. The pain is dull, unpleasant, but not acute. It starts about 2 hours after eating. Spicy food makes it worse and it is a problem because you like spicy food and fast food. While eating you feel full very early. You don't usually feel like eating. You are worried but you don't want to show it.

- You vomited twice 2 months ago, but you don't know exactly why. You didn't notice blood in the vomit. No weight loss. You belch from time to time. Constipation occurs rarely. Sometimes you are sick but it is difficult to say why; perhaps you are just tired and irritated. You also suffer sporadically from headaches - they start in the middle of the day or in the evening. You don't sleep very well and you feel a bit tired, but you are busy during the day, so it is not a problem.

- Three weeks ago you suffered from a sore throat. You took aspirin for 10 days. Now, you are fine.

- You had severe diarrhoea 4 years ago when you were abroad in Croatia. You contracted mumps when you were 5 years old in the kindergarten.

- You have never had any surgical operation.

- Your sister has asthma, your brother had a head injury last year. Your parents are alive and well.

- You live alone without any family in a small apartment and drive a car to work $60 \mathrm{~km}$ one way. You smoke occasionally: 2-3 cigarettes a week.

- You were promoted 6 months ago and you need to drive a car as you finish work late. You do not have time for "stupidities" like socializing or cooking meals for yourself. 
For those who played the part of doctors, the layout of a medical interview or history-taking was shown on a slide (see below). The interview should be conducted according to a particular order, so its main parts were provided in order to facilitate the dialogue. In a similar manner, like in a behavioural script ${ }^{1}$, how to end the interview remains conjectural. It means that it is not explicitly stated in the instruction. However, doctors, or other people familiar with the art of conducting the medical interview, know what comes at the very end.

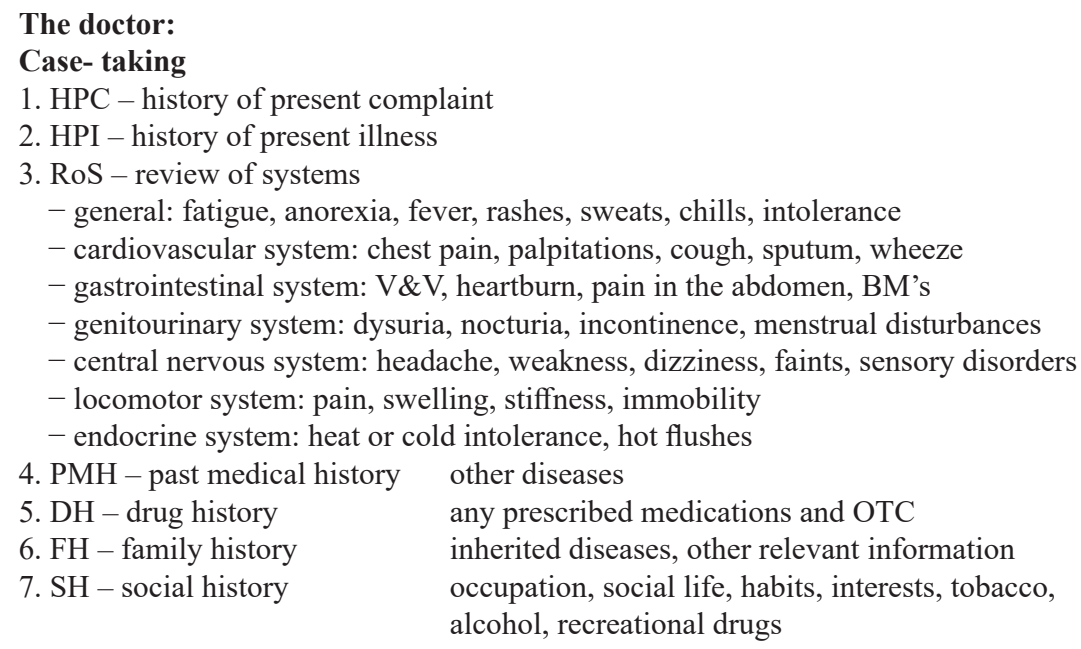

Source: J. Ciecierska, B. Jenike. English for Medicine. Podręcznik dla studentów medycyny. Warszawa, Wydawnictwo Lekarskie PZWL, 2007, p. 155-161

After the participants conducted conducting the medical interview, the author asked a few questions in order to check whether the task was completed.

What were the patient's symptoms?

Then, there was a question about the name of the diagnosed disease.

What is your diagnosis?

And the participants answered without much trouble: Peptic ulcer.

Participants were asked more questions to check the understanding of the patient's health problem:

1. Which organ systems were affected by the illness?

2. Was the past medical history contributory?

3. Was the drug history contributory? If so, why?

4. Was the family history contributory?

5. Was the social history contributory?

${ }^{1}$ Behavioral scripts are a sequence of expected behaviors for a given situation. https://en.wikipedia.org/wiki/Behavioral_script 
In order to answer them, the information from the task description is not sufficient. The participants must be aware of the implications of some medical facts. For example, they must know whether aspirin and smoking trigger peptic ulcer and this information is not stated in the task. Similarly, they need to possess the knowledge about complaints, and lifestyle which may be contributory to peptic ulcer. The author asked the "doctors" more questions which required independent thinking, reaching beyond the text and instruction.

How are you going to manage the patient about:

- irregular meals

- daily trips to work

- career-oriented ambition

- stressful lifestyle

- lack of social network

- lack of time for "stupidities"

What is your prognosis for the patient?

The last question could start a fact-based discussion among participants who consider both optimistic and pessimistic scenario. The participants were not expected to use creativity in answering these questions, only to rely on the facts elicited from the patients, combined with knowledge and experience inpatient management. For sure, they needed an open mind and logical thinking, too.

The instruction did NOT include the following two questions which are asked at the end of the interview by the doctor.

1. I am going to sum up what you have just told me? Can you correct me, if necessary?

\section{Is there anything else that you would like to add?}

The participants were not reminded about doctor's body-language, the need to speak clearly or to use patient's register, shaking patient's hand etc. Nonetheless, these details should be practised in a real interview. Thus, if students make mistakes because they do not remember how to conduct the interview with a patient, the role of the teacher is to revise the principles.

The final questions give the patient a chance to correct all possible ambiguities and be active from the very beginning in the process of treatment. The habit to ask the two questions is not often practised Poland. Time allocated per patient is short and doctors examining the patient try to save it by not recapitulating his/her words. The participants had the chance to discuss the benefits of the questions.

In the field of medicine, that kind of knowledge is supposed to be already known from books or lectures. Speaking in another language does not pose additional problem. Cummins (2008) pointed out positive transfer of knowledge between mother tongue and foreign languages. The transferability makes the com- 
prehension of a text simpler, but it does not help much when experience is lacking. The latter situation may be observed among medical students who do not have much experience and may have difficulty in decoding some texts.

Moreover, some terms and expressions which take on specific meaning may add to the difficulty in text comprehension. The meaning is different from a common meaning in general language. A medical term frequency means frequent urination, not "the fact or condition of occurring frequently". Patient management (used in case 1) is not the process of managing the patient; it is patient treatment in a broad sense involving diet, lifestyle, adequate hydration, etc. But this kind of difficulty is relatively easy to overcome compared to others. While reading a specialist text the reader needs particular attention focused on the text and beyond the text.

\section{GREEN TEA AND HEPATOTOXICITY - CASE 2}

The second part of the workshop introduced an abstract about a middle-aged female patient who needed a liver transplant after green tea consumption. Since green tea has been long known as healthy, at first glance, the situation looks surprising. The task for the participants was to employ a detective mind and consider other, perhaps concomitant, causes which might have contributed to the liver transplantation. Some facts from the patient's lifestyle are given in the abstract below.

\section{Green tea and hepatotoxicity (abstract)}

A previously healthy 42-year-old woman was admitted to hospital for investigation of stomach discomfort and jaundice. Upon admission, results of the patient's liver function tests were abnormal, her international normalized ratio (INR) was 5 (normal 1), her ammonia levels were elevated, and her CT scan was normal. Results of hepatitis B and $\mathrm{C}$ screens were negative. The patient's condition deteriorated; she became confused and encephalopathic and was comatose 9 days after admission. Fourteen days after admission the following abnormal laboratory findings were reported: direct bilirubin $234 \mu \mathrm{mol} / \mathrm{L}$ (normal < 4), total bilirubin $423 \mu \mathrm{mol} / \mathrm{L}$ (normal $<16$ ), alanine aminotransferase 432 IU (normal 1-20), aspartate aminotransferase 217 IU (normal 10-42), INR 3.4. The hepatic biopsy result was reported as "toxic hepatitis." A liver transplant was performed 17 days after presentation. For about 6 months before admission, the patient had been taking 6 capsules of Green Lite Polyphenon per day. This product contains a decaffeinated extract of green tea, providing $100 \mathrm{mg}$ of catechins per capsule. The product has been used for weight loss and is not authorized for sale in Canada. The reporter indicated that an unidentified flea spray was used at the patient's home, and the only concomitant medication was Depo-Provera injections, $150 \mathrm{mg}$ every 3 months, over the previous few years.

Source: Canadian Adverse Reaction Newsletter, January 2007; 17 (1): http://www.hc-sc.gc.ca/dhp -mps/alt_formats/pdf/medeff/bulletin/carn-bcei_v17n1-eng.pdf

\footnotetext{
${ }^{2}$ http://www.merriam-webster.com
} 
First, the question related to a safe daily allowance of green tea. During the workshop when participants signalled the need to know more about portions and consumption of green tea, the following information was presented. For this purpose, some literature search must have been done. The participants could become acquainted with the following slides which included a recommended daily portion, toxicological data, maximum tolerated dose and hepatotoxicity in an animal model.

\section{Recommended daily allowance of green tea}

The average person should not consume more than $10 \mathrm{mg}$ of extract per kilogram of body weight (10 $\mathrm{mg} \mathrm{x}$ body weight in $\mathrm{kg}$ ). For example, if you weigh $50 \mathrm{~kg}$, then you shouldn't consume more than $500 \mathrm{mg}$ of green tea extract per day. For all body weights, it is recommended to have no more than $750 \mathrm{mg}$ in one day.

It is difficult to exceed the recommended daily allowance when you are drinking green tea. A cup of green tea contains on average $80 \mathrm{mg}$ of EGCG. That means that you can drink quite a lot of green tea before reaching the danger zone.

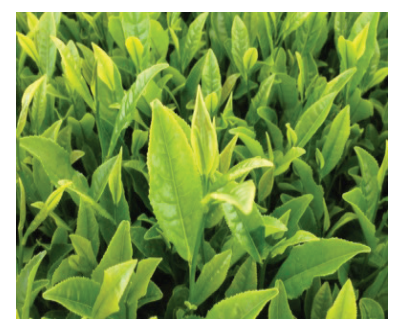

Source: http//www.green-tea-guide.com/green-tea-capsules.html

During the analysis of the abstract and the assessment of the gravity of the condition, participants were introduced to some analytical norms and the explanation of international normalized ratio ${ }^{3}$, if required.

\section{Toxicology}

Multidose pharmacokinetic studies suggest a daily dosage of $800 \mathrm{mg}$ /day of epigallocatechin gallate capsules (approximately equivalent to 16 Japanese-style cups of green tea) for up to 4 weeks, to be safe and well tolerated.

Source: https// www.drugs.com/npc/green-tea.html

${ }^{3}$ The INR is the ratio of a patient's prothrombin time to a normal sample, raised to the power of the ISI:

$\mathrm{INR}=(\mathrm{PT}$ patient $/ \mathrm{PT}$ normal $)$ ISI

The speed of coagulation is affected by levels of functional factor VII in the body, which requires vitamin $\mathrm{K}$. The prothrombin time can be prolonged as a result of deficiencies in vitamin $\mathrm{K}$, warfarin therapy, malabsorption, or lack of intestinal colonization by bacteria, poor factor VII synthesis (due to liver disease) or increased consumption (in disseminated intravascular coagulation).

- the normal range of INR is $0.8-1.2$,

- on warfarin therapy an INR of 2.0-3.0 is usually targeted,

- the target INR may be higher in particular situations, such as for those with a mechanical heart valve.

- A high INR indicates a higher risk of bleeding, while a low INR suggests a higher risk of a clot. (https://en.wikipedia.org/wiki/Prothrombin_time) 


\section{GREEN TEA (CAMELLIA SINESIS)}

Human clinical studies demonstrate that single doses of up to 1.6 grams of green tea extract are well tolerated. The maximum tolerated dose in humans is reported to be 9.9 grams per day; a dose equivalent to 24 cups of green tea.

Side effects of high doses of green tea extract are usually mild and include headache, dizziness and nausea. The safety and tolerability of long term use of green tea extracts has not been well defined.

Liver injury typically arises within 3 months, with latency to onset of symptoms ranging from 10 days to 7 months.

\section{US National Library of Medicine}

Source: https///livertox.nlm.nih.gov/GreenTea.htm

The aspect of human toxicology can be compared with similar effects in an animal model for the sake of scientific curiosity(relevant information is underlined).

\section{Hepatotoxicity of High Oral Dose (-)-Epigallocatechin-3-Gallate in Mice}

Lambert J. D., Kennett M. J., Sang S., Kenneth R. Reuhl K. R., Ju J., and Yang C. S.

The tea polyphenol (-)-epigallocatechin-3-gallate (EGCG) has been studied for chronic disease preventive effects, and is marketed as part of many dietary supplements. However, case reports have associated the use of green tea-based supplements with liver toxicity. We studied the hepatotoxic effects of high dose EGCG in male CF-1 mice. A single dose of EGCG $(1500 \mathrm{mg} / \mathrm{kg})$ increased plasma alanine aminotransferase (ALT) by 138fold and reduced survival by $85 \%$. Once-daily dosing with EGCG increased hepatotoxic response. Plasma ALT levels were increased 184-fold following two once-daily doses of EGCG $(750 \mathrm{mg} / \mathrm{kg})$. Moderate to severe hepatic necrosis was observed following treatment with EGCG. EGCG hepatotoxicity was associated with oxidative stress including increased hepatic lipid peroxidation.?/.../ Our results indicate that higher bolus doses of EGCG are hepatotoxic to mice. Further studies on the dose-dependent hepatotoxic effects of EGCG and the underlying mechanisms are important given the increasing use of green tea dietary supplements, which may deliver much higher plasma and tissue concentrations of EGCG than tea beverages.

Source: Food and Chemical Toxicology Volume 48, Issue 1, January 2010, pp. 409-416

The following abstract indicates another possible culprit of liver damage - Depo-Provera injections. Thus, the doses and possible unwanted effects were looked upon in a leaflet of the drug manufacturer (Pfizer). The information on a slide was limited to the extract describing dosage and administration of the drug.

\section{Depo-Provera: Dosage and administration}

The recommended dose is $150 \mathrm{mg}$ of Depo-Provera CI every 3 months (13 weeks) administered by deep, intramuscular (IM) injection in the gluteal or deltoid muscle.

Hepatotoxicity is uncommon (may affect up to 1 in 100 people).

Jaundice, and abnormal liver enzymes (blood tests used to measure liver function) may by present. 
Discontinue Depo-Provera CI use if jaundice or acute or chronic disturbances of liver function develop. Do not resume use until markers of liver function return to normal and Depo-Provera CI causation has been excluded.

This Patient Information has been approved by the U.S. Food and Drug Administration.

Source: https: //dailymed.nlm.nih.gov/dailymed/archives/fdaDrugInfo.cfm?archiveid=82498

Subsequently, a task was assigned in order to look for all possibly detrimental factors which could lead to the liver damage of the patient. In the reconstruction, a questioning process was encouraged. What is NOT in the text the knowledge of negative impact on the liver functions. The participants were given one or two examples, after which they could come up with many contributory questions. Some examples are given below.

1. What was her occupation? Was the patient exposed to any chemicals?

2. Did she live on a farm? Were fertilizers used in the neighbourhood?

3. Did she keep any pets or farm animals? Did she try to eradicatefleas? How many times - once or more? Were zoonoses excluded in her case?

4. What was her lifestyle:

What diet did she have? Did she add any other herbs to her everyday diet? How much alcohol did she use to drink?

How about tobacco and recreational drugs?

5. Had she ever been ill with the liver before? If yes, what was it?

6. What was her hobby? For example, had she used any paints before?

7. Was she ill before the hospitalisation?

8. Was she treated with paracetamol or another liver-damaging medication?

The participants managed this activity quite well. However, they were able to produce more questions if they knew about liver functions and damage.

\section{AN ACTIVE READER}

Following the two tasks, the issue arises what makes a good reader of specialist texts.

An active reader can ask and find answers to the questions. From Singer and Dolan's point of view (1989), text comprehension is a product and a process (as cited in Scull 2010, p. 88). In a comprehension process, readers ask themselves questions; when the text is seen as a comprehension product, the teacher prepares the questions. Advanced readers go through reading on their own without a teacher.

Similarly, Singer (1981) was of the opinion that an active reader is engaged in "a continuous process of asking and searching for answers to self-posed qu- 
estions" (as cited in Scull 2010, p. 88). During the workshop, the participants had an opportunity to articulate this kind of questions.

Active readers also had to be critical during the tasks. According to Aş1lığlu (2008, p. 7), a reader who is not critical ${ }^{4}$ cannot exceed the level of perception, while a critical reader may reach analysis, synthesis and evaluation. Critical reading often refers to points beyond the text. This attitude leads to better comprehension and, finally, readers remember what they have read and one text often constitutes the basis for more reading. Moreover, when they finish the reading process, the mental transformation of the significance is still in progress (Ferdi et al., 2014, p. 2445).

While reading a specialist text, the reader needs particular attention focused on the text and beyond the text.

\section{REQUIREMENTS FOR THE TEACHER OF LANGUAGES FOR SPECIAL PURPOSES}

Teachers of foreign languages are aware of the role to developing reading skills: first, while reading stories then informative and scientific texts (Lapp et al., 2013, p. 110). Although a purely linguistic basis is mandatory, it is not sufficient to achieve full comprehension and critical approach.

When teaching medical English, language teachers must be prepared and understand subject matter. They must know, among other things, symptoms, the rules of making the differential diagnosis, mechanism of physiological and pathological processes and be able to compare scientific data (e.g. lab tests). The final purpose of the teacher's preparation for class is to find an authentic text and real-life activity (Snow 2002, p. 56).

When teachers have to prepare specialist authentic texts, they gather information from many sources. Then they encourage students to make some scientific investigation: how relevant some facts are, e.g. using flea spray, what questions to ask, how to search for the explanation. After some time, students will develop the habit of questioning, checking necessary information and they will become familiar with specialist texts. This experience is also transferable from the first to second language (author's experience).

Perfetti (2001, p. 12809) believed that "the reader must import knowledge from outside the text". The knowledge of the subject usually comes from many other sources - specialist texts, books, lectures and conferences. Teachers may

${ }^{4}$ Critical thinking is correlated with originality of thought and is free from the pressure of authorities or a group (Plenkiewicz 1994, p. 76). 
point to different strategies that require going beyond the text, for example, how to search the literature and look for some explanations outside in different sources (Kolić-Vehovec et al., 2011).

\section{BIBLIOGRAPHY}

Akin F., Koray Ö., Tavukçu K., 2014, How Effective Is Critical Reading in the Understanding of Scientific Texts? Procedia - Social and Behavioral Sciences", 174 (2015), pp. 2444-2451.

Andrychowicz-Trojanowska A., 2010, Język specjalistyczny - Terminologia - Tekst, In: Roman Hajczuk (ed.), Linguodidactica XIV, Białystok, pp. 7-26.

Aş1lığlu B., 2008, Importance and Means of Improving Critical Reading for Cognitive Learning, "Journal of D.U. Ziya Gökalp", Faculty of Education, 10, pp. 1-11.

Cummins J. 2008, BICS and CALP: Empirical and Theoretical Status of the Distinction, In: Brian. Street \& Nancy H, Hornberger (red.), Encyclopedia of and Education, 2nd Edition, Vol. 2 Literacy, Springer Science +Business Media LLC, New York, pp. 71-83.

Daunis S., Iams M. C., 2007, Text Savvy. Using a Shared Reading Framework to Build Comprehension, Portsmouth.

Fisher D., and Frey N., 2012, Close Reading in Elementary Schools, "The Reading Teacher", 66 (3), pp. 179-188.

Gumowskaya G., 2010, Lingual systems o communication: LSP vs. LGP, In: Sambor Grucza, Adam Marchwiński, Monika Płużyczka (ed.), Studi@ Naukowe 7, Translatoryka. Koncepcja-Modele-Analizy, pp. 68-73.

Kolić-Vehovec S., Bajšanski I., Rončević Zubković B., Reading Strategies, Text Comprehension and GPA, "Review of Psychology", 2011, Vol. 18, No. 2, pp. 81-89.

Griffin L., 2005, Strategic Questioning for Sound Literacy Instruction, In: Scott Alan Hutchens (ed.), Special Edition Devoted to Reading Issue, Cleveland, MS, pp. 15-23.

Lapp D., Grant M., Moss B., Johnson K., 2013, Close Reading of Science Texts. What's Now? What's Next? "The Reading Teacher", Vol. 67, Issue 2, pp. 109-119.

Nation K., 2008, Children's Reading Comprehension Difficulties, In: Margaret J. Snowling and Charles Hulme (eds.), The Science of Reading: A Handbook, Oxford, pp. 248-265.

Norozi S. A., 2007, Reading beyond the lines, Dawn. [online] http://ecommons.aku.edu/pakistan ied pdck/56 (18.08.2016).

Perfetti C. A., 2001, Reading Skills, In: N. J. Smelser and P. B. Baltes (eds.), International Encyclopedia of the Social and Behavioral Sciences, Oxford, (pp. 12800-12805).

Perfetti C. A., 2007, Reading Ability: Lexical Quality to Comprehension, "Scientific Studies of Reading", 11 (4), pp. 357-383.

Plenkiewicz M. L., 1994, Z zagadnień krytycznego czytania w klasach początkowych. Próba diagnozy umiejętności krytycznego czytania uczniów klas trzecich szkół wiejskich, „Zeszyty Naukowe Wyższej Szkoły Pedagogicznej w Bydgoszczy. Studia Pedagogiczne”, z. 29, s. $71-83$.

Queensland Curriculum and Assessment Authority (QCAA), 2015, Beyond NAPLAN. How to Read Challenging Texts. [online] https://www.qcaa.qld.edu.au/downloads/p_10/naplan_read_challenging texts.pdf (20.08.2016).

Richards, I. A., 1929, Practical Criticism, London,England.

Sawicka A., 2009, Short Characteristic of Languages for Special Purposes, In: Stanisław Szadyko (ed.) Komunikacja specjalistyczna, t. II Specyfika języków specjalistycznych, Warszawa, pp. $188-198$. 
Scott A. H., 2005, Reading comprehension: a cognitive perspective, In: Alan Hutchens Scott (ed.), Delta Education Journal. Special Edition Devoted to Reading Issues, Delta state University, Cleveland MS, pp. 37-50.

Scull J., 2010, Embedding comprehension within reading acquisition processes, ,, Australian Journal of Language and Literacy", Vol. 33, No. 2, 2010, pp. 87-107.

Snow C., 2002, Toward an R\&D program in reading comprehension, RAND; [online] www.rand. org (17.08.2016).

Urszula Swoboda-Rydz

\section{(TRZEBA) WYJŚĆ POZA TEKST}

Słowa kluczowe: czytanie, rozumienie krytyczne, wiedza, doświadczenie

Streszczenie. Czytanie jest złożonym procesem, który jest nieodzowny w skutecznym rozwoju kariery naukowej. Podczas czytania tekstów specjalistycznych zachodzi konieczność przejścia przez poziom dosłowny, domyślny oraz twórczo-oceniający. Dla niedoświadczonego czytelnika, który już zapoznał się z podstawową terminologią z danej dziedziny, specjalistyczne teksty mogą stanowić trudność, ponieważ potrzebne jest mu również krytyczne podejście. To oznacza wykorzystanie doświadczenia i wiedzy, które są poza tekstem, oraz umiejętność zadania odpowiednich pytań. Wyjście poza tekst daje czytelnikowi szansę lepszego zrozumienia zagadnienia. Dwa przykłady wykorzystane podczas warsztatów dają przykład, jak nauczyciele mogą przygotować studentów do czytania tekstów specjalistycznych. 